\title{
Addressing the needs of seasonal migrants in Nashik, Maharashtra
}

Anjali B. Borhade

Follow this and additional works at: https://knowledgecommons.popcouncil.org/departments_sbsr-rh

Part of the Demography, Population, and Ecology Commons, Family, Life Course, and Society Commons, International Public Health Commons, and the Migration Studies Commons How does access to this work benefit you? Let us know!

\section{Recommended Citation}

Borhade, Anjali B. 2007. "Addressing the needs of seasonal migrants in Nashik, Maharashtra," Health and Population Innovation Fellowship Programme Working Paper no. 2. New Delhi: Population Council. 

This report is the result of a project entitled "Addressing the Sexual and Reproductive Health of Unorganised Seasonal Migrant Adolescents, Women and Youth," undertaken as part of the Health and Population Innovation Fellowship (HPIF) awarded to the author in 2004.

The HPIF programme is administered by the Population Council, New Delhi and is a continuation of the MacArthur Foundation's Fund for Leadership Development (FLD) fellowship programme that continued over the period 1995 to 2004. The Council is grateful to the MacArthur Foundation for its support to this programme.

The HPIF programme aims to support mid-career individuals who have innovative ideas, leadership potential, and the capacity to help shape policy and public debate in the field of population, reproductive health and rights in general, with a focus on two priority themes - maternal mortality and morbidity, and the sexual and reproductive health and rights of young people. Since the transfer of the programme to the Population Council through 2006, a total of 17 individuals have been supported under the HPIF programme.

\section{For additional copies of this report, please contact:}

Anjali B. Borhade

Disha Foundation

2, Wild Orchid

B/H-Ved Mandir, Tidke Colony

Trymbak Road

Nashik, Maharashtra

Phone: 0253-2583968

Email: foundation.disha@gmail.com; banjali@gmail.com
Population Council

Zone 5A, Ground Floor

India Habitat Centre, Lodi Road

New Delhi -110003

Phone: 011-24642901/02

Email:info-india@popcouncil.org

Web site: http://www.popcouncil.org/asia/india.html

The Population Council is an international, non-profit, non-governmental organisation that seeks to improve the well-being and reproductive health of current and future generations around the world and to help achieve a humane, equitable and sustainable balance between people and resources. The Council conducts biomedical, social science and public health research, and helps build research capacities in developing countries.

\section{Copyright @ 2007 Anjali B. Borhade}

About the author. Anjali B. Borhade, Director, Disha Foundation, Nashik, has a Master's degree in Social Work from Pune University and a Bachelor's degree in English Literature from Pune University. She also holds a Diploma in Labour Laws and Labour Welfare. She has worked extensively with inter- and intrastate migrant and tribal populations in Maharashtra.

Suggested citation:A.B. Borhade. 2007. Addressing the Needs of Seasonal Migrants in Nashik, Maharashtra. Healtb and Population Innovation Fellowship Programme Working Paper, No. 2. New Delhi: Population Council.

\section{(P) Population Council}




\section{Addressing the Needs of Seasonal Migrants in Nashik, Maharashtra}

Anjali B. Borhade

Fellow

Health and Population Innovation Fellowship Programme 


\section{Contents}

Introduction

1

Situation of seasonal migrants in the project area

2

The needs of seasonal migrants in the project area

4

Strategies and interventions

8

Promoting good health practices and facilitating access to health care 9

Access to basic services: Water supply, shelter and social security 11

Access to essential foodgrains: Issue of ration cards 12

Access to child services: Birth registration, child care and education 14

Building livelihood skills 18

Access to financial security: Promoting savings and insurance 20

Conclusion and lessons learned 22

References 24

Acknowledgements 25 


\section{List of Tables}

Table 1: Profile of the migrant population in the four nakas in Nashik 3

Table 2: Facilitating migrants' access to health care through project support 10

Table 3: Addressing seasonal migrants' basic needs through project support 21 


\section{Introduction}

Migrants are generally defined as those observed (in a census or survey) as residing outside their place of origin or last residence. Mobility or temporary migration is characterised by a high degree of circulation of people (sometimes seasonal) and continuous contact between place of origin and destination. Temporary or seasonal migrants reside in destinations for a short period of time, and are hence not as likely to be captured in censuses and surveys; they include, for example, seasonal daily wage workers.

Short-term livelihood movement between villages and from villages to urban settings is observed to be associated with considerable social vulnerability, exhibited most acutely by its link with HIV risk, for example in Southeast Asia (Skeldon, 2000). The vulnerability of this mobile population of seasonal migrants has been attributed to a number of factors. This group tends to be young (in many cases less than $50 \%$ of all migrants are aged 15-24), relatively poorly educated, unskilled and with few economic resources. These short-term migrants often move out of traditional family and other social networks, and experience a lack of social control and sources of support in the new environment, conditions linked to casual or sex worker relations and heightened risk behaviour with non-sex workers. They often remain socially excluded in the destination cities and have considerably less access, in practice, to IEC programmes, public services including health and education, and even to such basic facilities as housing, water and food security (see for example, Guest, 2002).

Seasonal migrant populations are observed in many urban areas in India, and our understanding of the full range of their needs and the strategies required to address the vulnerabilities of mobile populations in destination cities is limited. In order to identify the opportunities and options available to address the vulnerabilities of one such mobile population, an intervention project was launched by the NGO, Disha Foundation, in Nashik city, Maharashtra. This report intends to use the project experience as a case study to provide a blueprint for interventions for seasonal migrants to access a range of basic services in areas of destination and to exercise their rights to access available services.

Although this intervention project was intended to address and meet the sexual and reproductive health needs of this population of seasonal migrants, it soon became clear that sexual and reproductive health comprised only part of their wide-ranging social and economic needs; hence the project widened its focus and devised strategies to meet an expanded set of priorities. This report documents the array of strategies used to enable seasonal migrants to recognise their entitlement and to access available public sector health, education and other social services. At the same time, it underscores the mediating role that the project played in sensitising government and public sector service providers about recognising the rights and accommodating the special circumstances of seasonal migrants in accessing public services on the one hand, and apprising seasonal migrants of their rights and mobilising them to avail of public sector services on the other.

1 Addressing the Needs of Seasonal Migrants in Nashik, Maharashtra 


\section{Situation of seasonal migrants in the project area}

Compared to other states in India, Maharashtra reports the largest number of net migrants (2.3 million; RGI, 2001) in the 1991-2001 decade. While Mumbai is the leading destination area for rural-urban migrants, other cities in Maharashtra, such as Nashik, have also attracted large rural populations.

Nashik has a population of 1,152,048 (RGI, 2001). A profile of the migrants covered by the project suggests that Nashik has a large number of seasonal workers. However, it is difficult to accurately assess their numbers as they are a mobile and floating population. Seasonal migrants to Nashik are both intra- and inter-state, coming from other districts and regions of Maharashtra (Dhule, Jalgaon, districts of Marathwada and Vidarbha), and other states (for example, Andhra Pradesh, Bihar, Gujarat, Karnataka, Madhya Pradesh and Uttar Pradesh). Seasonal migrants also belong to a number of tribal groups. As in other urban sites, a large proportion of Nashik's seasonal migrants are daily wage labourers who have distinct needs and face greater vulnerabilities than other migrants to the city.

Seasonal migrants in Nashik typically seek work in the city for 8-10 months of the year, between October and June. The pattern of migration corresponds with the agricultural seasons; they stay in the city during the lean season and return to their own villages during the monsoon or at other peak periods. Seasonal migrants generally seek employment at nakas, or established points in the city that are approached by contractors and others seeking to recruit daily wage workers. A total of nine such nakas dot the city of Nashik.

Temporary and unauthorised dwelling areas are set up in close proximity to these nine nakas — in vacant areas in parks (maidans), footpaths and so on. Dwelling units are generally makeshift and open, comprising no more than an open space in which the migrant family's belongings and cooking equipment are deposited, and where the family cooks, eats and sleeps. Only rarely are these dwelling spaces covered by canvas or plastic or tin sheets. These unauthorised dwelling areas are poorly serviced, without the provision of basic facilities such as water and sanitation. Moreover, there is no security for the family's belongings or physical security for migrant women.

This intervention project was undertaken among the populations of four of the nine naka areas of the city—Satpur, Peth Phata, Old Gangapur and Civil—during the period October 2004 to June 2005. Estimates suggest that at peak times the four nakas housed approximately 3,000 temporary migrants. The project undertook activities with over a thousand seasonal migrants and their families, ranging from approximately 92 to 356 persons in the four nakas. A profile of the populations of these four nakas suggests that they comprised a total of approximately 351 families. While some 122 households comprised men residing either alone, or with male relatives and friends, the remaining 229 households comprised men living with their wives and in most cases their children as well. 
For the most part, seasonal migrants are in the age group 20-29 years (see Table 1). The age distribution differs among males and females. While for both males and females, the largest population group is aged $20-29$ years (34.6\% of males and $33.0 \%$ of females), children (less than 15 years) comprise about one-third of the population for girls $(30.4 \%)$ and just under one-quarter for boys $(22.3 \%)$. In the age group 30-39 years, the proportion of men was higher than women $(20.1 \%$ vs. $13.3 \%)$. Boys and girls aged $15-19$ years are evenly distributed $(11.7 \%$ vs. $12.0 \%)$.

Seasonal migrants generally move to Nashik with their families, and reside in nuclear units in the city; while most are married, single men, widows and separated women also form the migrant population. The average size of the household is 3. Most seasonal migrants seek work as daily labourers providing unskilled services; men usually work as manual labourers while women are employed as domestic workers, head-load transporters or agricultural workers. Some children also work and contribute to the family income. Literacy rates are generally low.

\section{Table 1:}

Profile of the migrant population in the four nakas in Nashik

\begin{tabular}{|l|c|c|c|} 
& Male & Female & Total \\
\hline Total population & 566 & 457 & 1,023 \\
\hline$\%$ aged: & & & \\
$<15$ & 22.3 & 30.4 & 25.9 \\
$15-19$ & 11.7 & 12.0 & 11.8 \\
$20-29$ & 34.6 & 33.0 & 33.9 \\
$30-39$ & 20.1 & 13.3 & 17.1 \\
$40+$ & 11.3 & 11.1 & 11.2 \\
\hline
\end{tabular}

Note: All figures are approximate.

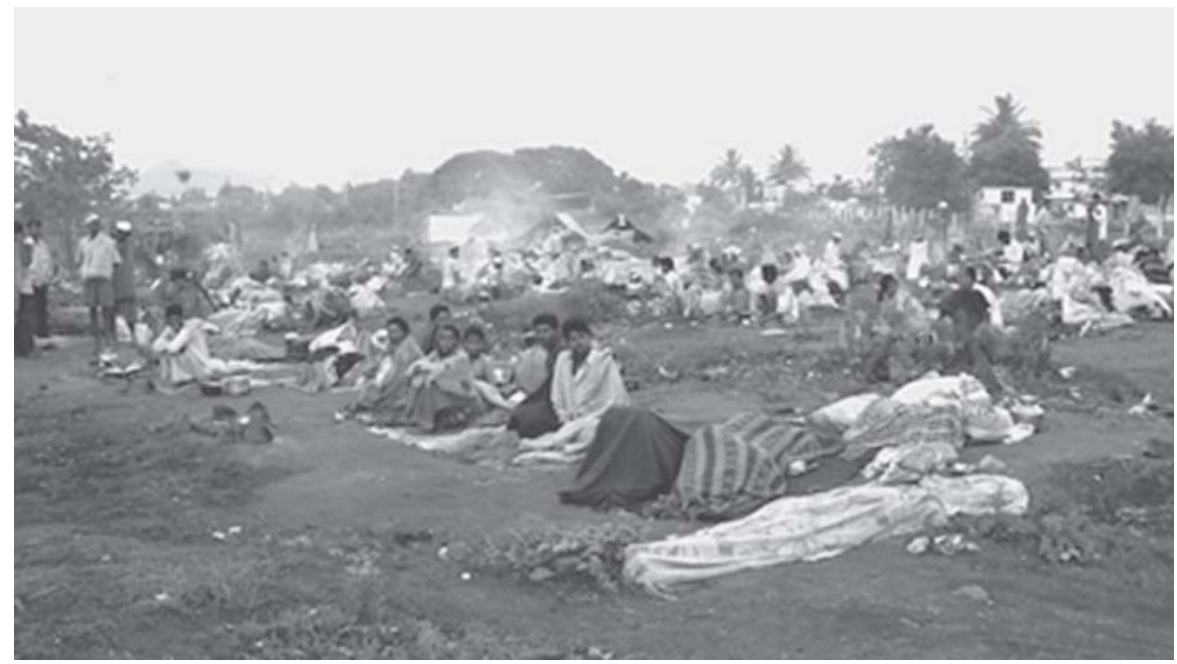

Housing situation of seasonal migrants

3 Addressing the Needs of Seasonal Migrants in Nashik, Maharashtra 


\section{The needs of seasonal migrants in the project area}

An informal assessment of the situation of seasonal migrants in the four nakas undertaken at the initial stages of project implementation highlighted a host of needs, and required a major reorientation of project activities and strategies. As can be seen from the following narratives from informal discussions, seasonal migrants lack access to basic amenities, including water and toilet facilities, shelter and electricity. Irregular employment and the casual nature of work results in economic and food insecurity as well as economic exploitation as wages are unregulated, promised wages not always paid or payments unnecessarily delayed.

I don't have any privacy as we stay on the roadside in the open. I have to bathe when it is dark and other migrants are sleeping. It is very difficult... after 6-7 a.m. the naka is very crowded and I can't bathe at that time. (Female migrant, 19 years, Old Gangapur naka)

It was very difficult for me to stay in the naka with two daughters; often, we don't get work. for 15 20 days a month. Often we don't have food to eat. (Female migrant, 34 years, Satpur naka)

My busband left me because I didn't have a child after three years of marriage; he has now remarried.... I migrated with my aunt.... But we don't get work for 10-15 days in a month. (Female migrant, 19 years, Satpur naka)

I have not got work. for the past 5 days. The foodgrain that I brought from my village is about to finish. I'm worried about my family; if I don't get work in the next few days, what we will eat, and bow we will go back to our village? (Male migrant, 32 years, Peth Phata naka)

By and large moreover, seasonal migrants lack awareness of health promoting practices and their entitlement to health, education and other services in Nashik, and consequently do not access public services and benefits. As a result, migrant children rarely attend school. Because seasonal migrants have limited child-care options, many children accompany their parents to the work site or remain in the naka unattended.

In the area of health, lack of knowledge of their right to public services is a major obstacle in accessing care. Many do not know where local health facilities are located and how to access services. They resist seeking treatment because of associated costs, because they are unable to leave their children behind in the naka, or because economic compulsions make it difficult for them to miss work. Moreover, access to health care is limited as providers do not recognise the need to meet the specific requirements of seasonal migrants. Sexual and reproductive health is also compromised as few have access to services or supplies, including contraceptives. 
Sometimes someone in the family is very sick and can't go to work. However, we have never dared to visit a doctor. We are scared that the doctor will ask. for a large sum of money as a fee. We don't have money for food, so how can we pay the doctor? The doctor may also ask us to buy medicine. So we take herbal medicine. (Female migrant, 20 years, Peth Phata naka)

I visited the doctor once when I had injured my foot .... I went to the urban health centre for treatment but the nurse asked me to go to the civil hospital. I did not have any money for transport so I could not go to the civil hospital. My foot was swollen and I could not walk, so I was not able to work. for a month. It was a very hard time for me and my family. (Male migrant, 20 years, Peth Phata naka)

One day a monkey bit me .... I visited the nearby government hospital, but the doctor told me to go to the civil hospital as they do not treat monkey bites. I did not have the money for transport. So I tied a cloth on the wound, and when I went to my village after a week, I was treated at the primary bealth centre. (Female migrant, 65 years, Satpur naka)

My wife was in labour so I took her to Bytco hospital [a municipal corporation hospital]. The nurse asked me to pay Rs. 400 for admission. I requested the nurse to admit my wife while I arranged for the money, but she refused. I took my wife back to the naka where she delivered the baby. (Male migrant, 28 years, Bytco point, Bytco naka)

I was scared to go to the government hospital because I felt I was not a resident of Nashik. As I stay in Nashik only temporarily, I feel I don't have the right to use the health services in the city. So I have never visited the government hospital which is very close to the naka. (Male migrant, 21 years, Peth Phata naka)

Hospitals are for rich people and not for labourers like us. (Male migrant, 38 years, Old Gangapur naka)

I took my wife to the government hospital; she had fever and a cold, but the doctor said that she could not treat my wife. I did not ask her why. (Male migrant, 21 years, Satpur naka)

I had all my deliveries in the naka; my husband and mother-in-law conducted all the deliveries. We have always been afraid that if we go to hospital they will charge high fees. (Female migrant, 38 years, Old Gangapur naka)

As among mobile populations elsewhere (see for example, Delor and Hubert, 2000; World Bank, 2002), sexual risk taking is reported in the intervention sites; some migrant women report exchanging sex for food security and housing. Women's vulnerabilities are reflected in the following quote and case studies (see Box 1).

A man offered to provide me a room on rent and a regular supply of foodgrain if I stayed with him. I didn't have an option, so I agreed. (Female migrant, 34 years, Satpur naka) 


\section{Box 1}

\section{Women's vulnerability in the naka}

\section{Exchanging sex for food security}

Savitri* had initially migrated to Satpur naka with her husband and children. When her husband deserted her and her daughters got married and left home, she stayed on alone in the naka.

Savitri could not find work for two months so she started begging. A contractor suggested that they have a sexual relationship, in return for which he would provide her with foodgrain and rent a room for her. She agreed as she had no other option.

She soon realised she was pregnant. Although she did not want to have the child, she could not have an abortion because she was already in the fifth month of pregnancy.

Savitri gave birth to a baby boy. As her financial situation was poor, she was concerned about how she would support the child. She decided to sell her son to a couple in the naka for Rs. 5,000 and $50 \mathrm{~kg}$ of rice. However, when other women in the naka came to know about this, they insisted that she take her child back. Savitri finally decided to return the money and take her son back.

\section{Risk taking behaviours}

Ganga* migrated to Old Gangapur naka and started living with her brother after her father died. She married a construction worker but after a few days, her husband deserted her and married another woman. Her brother refused to let her stay with him. To support herself, she started working as a daily wage labourer.

Meanwhile, a migrant suggested that she live with him in the naka, and promised to marry her and take her back to his village. She agreed as she did not have any other means to support herself. However, she found out that he was already married and had two children in the village.

As Ganga was pregnant, she continued to stay with her 'partner' at the naka. She delivered a child at the civil hospital and started work again. Her 'partner' meanwhile returned to the village leaving her to take care of her daughter. At the time, she was pregnant again. Her 'partner' came back after 4 months, and after her second delivery, left again for the village. She now has three daughters and is currently pregnant.

Ganga is constantly under stress as her children are not keeping well. She is also worried that if she has another daughter her 'partner' will sell the baby or kill her. Although she would like to undergo sterilisation, she has not discussed this with her 'partner' because she feels that he will not agree until she gives birth to a son.

Savitri's and Ganga's stories reflect the vulnerability of women who live in the naka, and the lack of support networks that heightens their situation.

*names have been changed. 


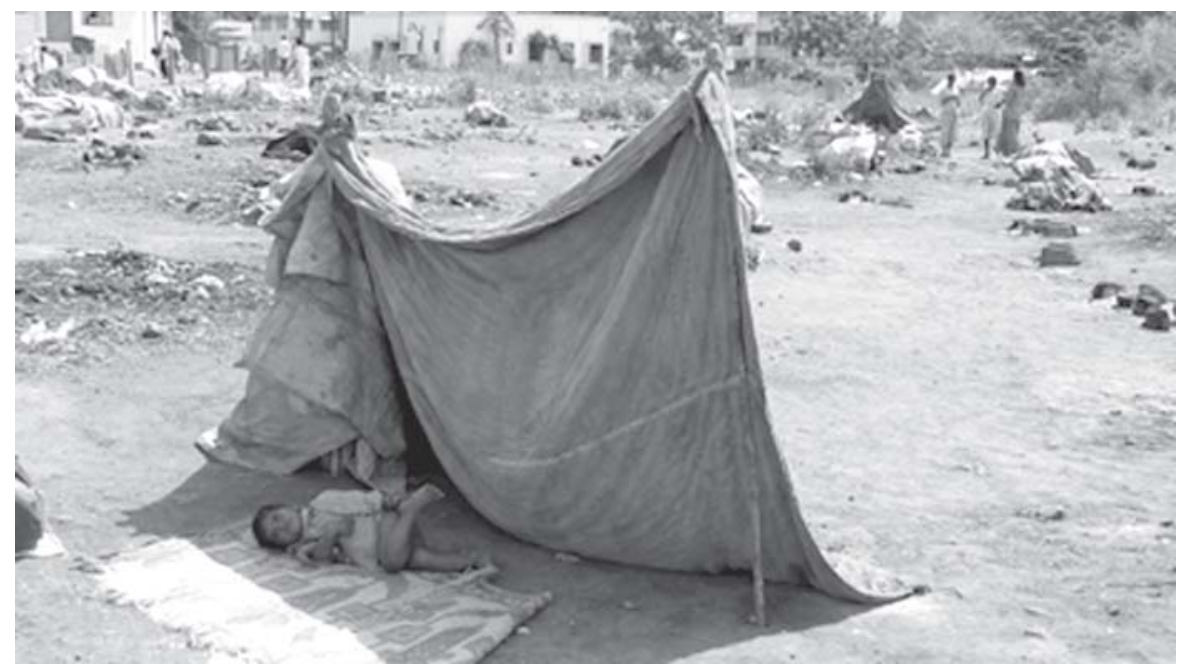

Vulnerability of children of seasonal migrants

In short, seasonal migrants in the intervention sites had multiple needs, including access to health services, food, shelter and basic amenities such as water and sanitation, child-care facilities, schooling for children, livelihood opportunities and skills, and access to financial security. When particularly at risk, sex often becomes a survival strategy. 


\section{Strategies and interventions}

It became clear from discussions with seasonal migrants that a narrowly-defined intervention - in this case to enhance sexual and reproductive health — would not be feasible for this group. Indeed, it was evident that in order to influence sexual and reproductive health, there was a need for a more comprehensive approach with an expanded set of strategies to address the whole range of basic needs of the population. In fact, during informal discussions, seasonal migrants themselves identified their need for a larger array of services in addition to health; for example, access to basic amenities such as water supply, food security, schooling and child-care facilities, livelihood skills building to enhance employment opportunities, and access to financial security.

In addressing all of these needs, project activities took place at both the level of the individual migrant and the family, and at the level of the service provider, programme manager and policy maker. At the level of the individual and the migrant community, the intervention apprised seasonal migrants of their rights, identified the services to which they are entitled, facilitated their use of these services, and finally built the necessary skills to enable them to assert their rights to avail of these services independently of the project. In all of these activities, staff members held individual and naka level sessions to familiarise seasonal migrants with available services and to build skills to enable them to access these services. Some 57 on-site visits were organised by the project to the four nakas to link seasonal migrants to a host of services, including health, and to provide information on basic services, vocational training, and health referral and immunisation.

At the level of the service provider, programme manager and policy maker, the project mediated with the state and local government, health and other service providers to help seasonal migrants avail of services. Initially, their response was not very encouraging, as providers, programme managers and the administration more generally felt that providing services to seasonal migrants in Nashik city would create a pressure on the existing infrastructure. It was also felt that the needs of seasonal migrants should be addressed by the administration in their own villages of origin rather than in the destination city. However, following a series of meetings, presentations and slide shows and by flagging Government Resolutions pertaining to the rights of seasonal migrants, the team was able to sensitise the authorities to the need to address seasonal migrants' rights. What is important is the extent to which the project used the existing system to enable seasonal migrants to gain food security, child-care and schooling for their children, and health care and other amenities and services. Strategies and interventions adopted by the project are discussed in this section in the context of each of the services provided (see Tables 2 and 3 for details). 


\section{Promoting good health practices and facilitating access to health care}

As mentioned earlier, health—sexual and reproductive health in particular-was the original focus of the project and also a key priority identified by temporary migrant communities. Moreover, seasonal migrants lacked awareness of good health practices and of their right to use health facilities. They were also unable to navigate the health system to access services; those who did manage to access services reported poor quality of care.

At the level of the migrant community, the project worked to raise awareness of health promoting practices, inform seasonal migrants of their right to avail of public health facilities and enable those in need to navigate the public health system. Awareness building activities included one-on-one counselling sessions, group discussions, film shows, poster displays and theatre. Sessions were organised at appropriate timings to suit the convenience of seasonal migrants. In addition, in order to overcome seasonal migrants' fear of accessing and reluctance to use public health facilities, project representatives played a facilitating role by accompanying seasonal migrants to nearby health facilities and sensitising them about how to use the services, including where to get their case record and the location of different wards. Seasonal migrants were also made aware of how they should report their case histories, and how to interpret prescriptions and comply with treatment.

At the level of providers and health authorities, the project undertook sensitisation activities to apprise providers of the compromised situation of seasonal migrants and the need to enable migrant clients to overcome their fear of accessing health facilities and providers. The response of providers was positive and several agreed to make services available at the nakas: some 33 site visits were organised in the four nakas, at which seasonal migrants were treated for a range of ailments, information was provided on personal hygiene, immunisation services provided for children and referrals made if necessary. These visits also helped health service providers to better understand the living conditions and health risks faced by seasonal migrants.

For those requiring facility-level care, the project set up a referral system at the naka that enabled seasonal migrants to access care at nearby government hospitals and health centres. Following a severe infection of scabies at Satpur naka, for example, the project referred seasonal migrants to a local hospital for treatment. The project also advocated with the state government on another key concern-malnutrition among migrant children. As a result of consultations with staff from the Integrated Child Development Services (ICDS), and a visit to the naka by the authorities, children aged 6-12 with malnutrition were linked up to nearby balwadis. The project has mobilised parents to send their children regularly to the balwadis to ensure that they have access to nutritional supplements.

The project paid special attention to raising awareness of safe sexual behaviours, of contraception and pregnancy-related care. Awareness of reproductive health issues is low and many seasonal migrants have misconceptions or incorrect knowledge of these issues, including transmission of HIV. In addition, seasonal migrants reported

9 Addressing the Needs of Seasonal Migrants in Nashik, Maharashtra 
considerable unmet need for contraception, and lack of awareness of non-terminal methods, their use and location of supplies. Infertility was a major concern, as a result of which several women reported that they had been deserted by their partners.

Some months ago I realised that I hadn't got my period... I was very scared. I didn't know about oral contraceptive pills or condoms... If I had known earlier I could have avoided this pregnancy. (Female migrant, 34 years, Satpur naka)

To address risks and raise awareness, counselling sessions were organised for seasonal migrants and their families on sexual and reproductive health. Sessions covered contraceptive use; reducing unmet need for contraception; menstruation, pregnancy and pregnancy-related care; drug/alcohol addiction; domestic violence; and HIV/sexually transmitted infections (STIs) and other infections. Premarital counselling sessions were also organised. A major focus of the intervention has been to build awareness about infertility and services for treatment.

Many seasonal migrants reported the need for temporary contraceptives. During visits to the naka, health care providers distributed oral contraceptives and condoms, and the project team undertook activities to enable seasonal migrants to obtain re-supplies of contraceptives from nearby hospitals. Finally, in view of risky sexual experiences, the project has recently requested the Nashik Municipal Corporation to implement a roaming voluntary counselling and testing cell (VCTC) at each naka. At present VCTC services

Table 2:

Facilitating migrants' access to health care through project support

\begin{tabular}{|c|c|c|c|c|c|}
\hline & \multicolumn{5}{|c|}{ Number of } \\
\hline & $\begin{array}{l}\text { Counsel- } \\
\text { ling } \\
\text { visits by } \\
\text { project } \\
\text { staff* }\end{array}$ & $\begin{array}{l}\text { On-site } \\
\text { visits by } \\
\text { healthcare } \\
\text { providers }\end{array}$ & $\begin{array}{l}\text { Migrants } \\
\text { given } \\
\text { contraceptive } \\
\text { supplies by } \\
\text { the project }\end{array}$ & $\begin{array}{l}\text { Migrants } \\
\text { taken by } \\
\text { project staff } \\
\text { to a health } \\
\text { facility }\end{array}$ & $\begin{array}{l}\text { Migrants } \\
\text { accessing a } \\
\text { health care } \\
\text { facility on } \\
\text { their own }\end{array}$ \\
\hline Contraception & 445 & 8 & $\begin{array}{l}61 \text { women** } \\
91 \text { men*** }\end{array}$ & 151 & 76 \\
\hline $\begin{array}{l}\text { Sexually } \\
\text { transmitted } \\
\text { infections }\end{array}$ & 530 & $8^{\#}$ & - & 140 & 73 \\
\hline $\begin{array}{l}\text { Skin and other } \\
\text { infections }\end{array}$ & 532 & 25 & - & 202 & 138 \\
\hline
\end{tabular}

Note: All figures are approximate.

* includes one-on-one visits to migrants and on-site visits by health providers.

** women were given oral contraceptives.

*** men were supplied condoms.

\# covered family planning issues.

- not applicable. 
are available only at a hospital that is located some distance from the nakas and is inaccessible to seasonal migrants.

The project has effectively built a demand for contraception among the migrants. As a result of the intervention, 152 migrants have accessed oral contraceptives or condoms and two women have opted for sterilisation. Moreover, following project efforts, seasonal migrants have begun to access health care facilities on their own; 76 men and women tracked by the project visited a facility specifically for contractive services while an almost equal number (73) sought care for STIs.

\section{Access to basic services: Water supply, shelter and social security}

Seasonal migrants had identified the need for basic amenities, including water supply, sanitation, shelter and social security, as a leading priority. The project organised seven on-site visits by authorities concerning water, sanitation, shelter and electricity.

\section{Water supply}

The project raised with the authorities the need to supply water to residential areas in the nakas. Government authorities were initially reluctant to address the issue: they cited such difficulties as the paucity of water tankers, the inability of the community to pay for water services and the misconception that unauthorised settlements were not eligible for publicly supplied water.

Advocacy efforts were made to sensitise the state and local administration to the needs of the migrant population and the obligation of the state to provide them basic services during their period of temporary migration. Although the project had made regular attempts earlier to convince the authorities to supply water, an outbreak of scabies provided an additional justification for the provision of water. Project representatives apprised government officials of the outbreak of scabies in one naka and the extent to which lack of water contributed to its spread. At the same time, in other advocacy efforts, the project facilitated an on-site assessment of the situation and potential for the spread of disease, and a meeting between officials of the Nashik Municipal Corporation and residents of the naka.

These efforts convinced Corporation authorities of the need for a regular supply of water to the nakas to curb the spread of the disease (if not to meet seasonal migrants' rights). An order was issued to supply water once a week to the naka for the duration of the epidemic. Unfortunately, this was not a sustained activity, and the authorities could ensure access to water for 250 families for only a month for the duration of the epidemic.

11 Addressing the Needs of Seasonal Migrants in Nashik, Maharashtra 


\section{Shelter}

As noted earlier, another key priority articulated by seasonal migrants was the need for shelter in the naka. In response, project representatives approached the Collector, Tribal Development, Nashik and the Nashik Municipal Corporation to enlist their cooperation in providing temporary shelter for seasonal migrants with amenities such as water, sanitation and electricity. Following the intervention of the project staff, the state administration has taken on the responsibility of setting up a transit camp for seasonal migrants in one of the four nakas (Peth Phata naka). The Collector, Nashik has provided the land to set up the camp, the Department of Tribal Development has agreed to provide financial support (for tribal residents), while the Maharashtra State Electricity Board (MSEB), the Public Works Department, the Department of Water Supply, the Zilla Parishad and the Nashik Municipal Corporation will provide technical support. These efforts are currently under way.

\section{Social security}

To address concerns identified by seasonal migrants regarding issues related to social security, the project has advocated with the Labour Commissioner, Nashik to provide identity cards to seasonal migrants that can be used in cases of police harassment, wage exploitation, etc. Meanwhile, the project has issued temporary identity cards to seasonal migrants who are part of its union for unorganised workers, which can be used by seasonal migrants till government identity cards are issued. Seven visits to the nakas were organised for the police to discuss with seasonal migrants issues of protection at night.

Following sustained efforts by the project, a Board is being set up, with representatives from Nashik Municipal Corporation, the Labour Department and seasonal migrants themselves, to address issues of wage exploitation. Meanwhile, the project has linked up with seasonal migrants, and cases of wage exploitation, cheating and non-payment of wages are being referred to the Labour Department.

The project is also mediating with government authorities and seasonal migrants to get the authorities to issue certificates to establish their Scheduled Caste and Scheduled Tribe status, which would entitle them to several benefits including free vocational training.

\section{Access to essential foodgrains: Issue of ration cards}

Access to subsidised foodgrain was another priority identified by seasonal migrants. Seasonal migrants noted that unlike permanent residents of Nashik whose family incomes fell below the poverty line, they did not have access to ration cards and therefore to regular supplies of subsidised foodgrains. At the same time, irregular employment opportunities resulted in acute food scarcity, such that some acknowledged that their women and children were made to beg in the streets to supplement the family income. Indeed, anaemia and malnutrition were commonly observed among seasonal migrants in all four nakas. 


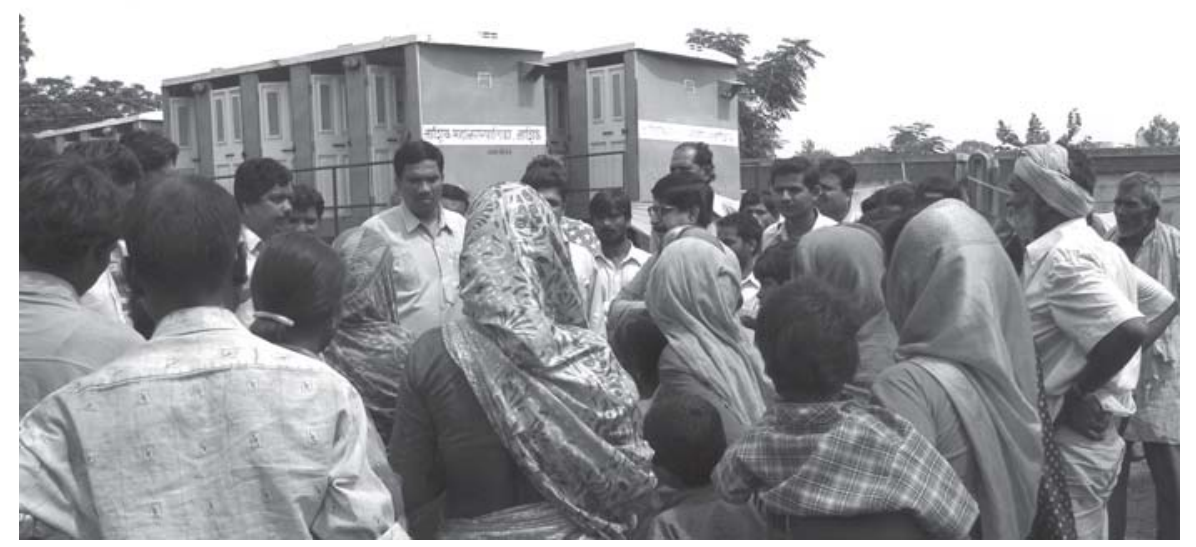

A project initiated on-site visit by government officials

In researching the rights of seasonal migrants to public distribution services, project representatives became aware of a Government Resolution (GR), issued in 2000, that asserted the right of seasonal migrants to access and use a temporary ration card during their stay in a destination city (see Box 2) and the obligation of each Collector to issue these temporary ration cards.

\section{Box 2}

\section{Extract from the State Government Resolution 1000/G.R.399/2000/NP28 issued on 9 November 2000 for providing ration cards to migrant (temporary) and unorganised workers in urban areas}

...as workers in the unorganised sector migrate in search of employment, do not reside in a fixed place and do not live in their native place, they do not have documentary proof, such as a birth registration certificate or a certificate for school enrolment for their children.

It is also very difficult to get documentary proof on migration. Since these families are generally eligible for services under the Public Distribution System, the requirements of documentary proof are hereby relaxed.

The normal procedure for getting a ration card - to complete an application formshould be observed on the basis of this information being given by the applicant; the Supply Inspector should physically verify the living conditions of the family members and then the procedure to issue temporary ration cards for a certain period should be adopted.

If the family wishes to reside at the same address for a longer period, the ration card should be renewed for such further period as necessary...

(Translated from Marathi) 
Using this Government Resolution, project representatives again played a mediating role between the state government authorities and the migrant community. They apprised the authorities - themselves unaware of the Government Resolution, its implications for seasonal migrants and their own responsibilities-about their role in providing ration cards to seasonal migrants. Following consultations with representatives of the Public Distribution System and the Ration Department, and three on-site visits by the authorities, an order was issued to provide seasonal migrants with temporary ration cards for four months (extendable to 12 months) against their existing ration cards. Seasonal migrants must have the cards cancelled by the ration department when they depart for their areas of origin so that they are eligible once again for subsidised foodgrain in their home villages; the cards can be renewed on their return to Nashik.

Thus far, project representatives have facilitated the issue of 25 temporary ration cards and recipients are eligible to purchase foodgrain at a concessional rate from ration shops close to their naka. Several have, moreover, been assisted to undertake activities required to extend the validity of their ration cards on their own, prepare their own applications and negotiate with ration office staff independently of project representatives.

Although the number of beneficiaries is small, and these efforts benefited only 25 out of the 351 families in the four nakas, the intervention demonstrates that it is possible for seasonal migrants to access services to ensure food security. However, efforts are needed to institutionalise the process so that entire communities can benefit.

\section{Access to child services: Birth registration, child care and education}

Seasonal migrants expressed concern that their children were ineligible for schooling in Nashik, that children were frequently left unattended while their parents worked, or that they accompanied their parents to work sites that were not always safe for young children, and that they were severely malnourished. Project representatives addressed these concerns in three ways: they enabled the practice of birth registration, established child-care centres for pre-school migrant children, and facilitated the enrolment of children in schools.

\section{Issue of birth registration certificates}

During 2004-5, a number of NGOs in Nashik campaigned for universal birth registration and worked with the project to raise awareness of the need for birth certification among migrant communities. In the course of activities, seasonal migrants were apprised of the importance of birth certification and the extent to which lack of birth certificates, a prerequisite for school enrolment, could deny their children an education. Interested seasonal migrants were, moreover, informed about the process, the cost, the time it would take for the certificate to be issued and the use of the certificate. Those who voluntarily opted were assisted in court to apply for an affidavit and then with the application for birth certificates from the Nashik Municipal Corporation. Despite migrants showing an interest, unfortunately only a total of seven birth certificates were thereby facilitated. 


\section{Child-care centres}

A key concern of parents was the safety and welfare of their children while they were out at work. To address this need, the project set up a day-care centre for the children of seasonal migrants at Old Gangapur naka. Through the day-care centre, the project initiated the process of school enrolment for the children as well as birth certification. At the peak, approximately 80-100 children aged 3-12 years attended the centre. Subsequently the daycare facilities for children under 5 years were integrated with the Nashik Municipal Corporation balwadi, and all the children enrolled in the centre were transferred to the balwadi.

Parents also identified the need to address the problem of malnutrition in children in the nakas. The project followed up with officials in the ICDS Department to facilitate the attendance of migrant children at anganwadis, which would address this problem. The project also followed up with the ICDS Department, Nashik, to put in place the central government guidelines that allow all migrant children to avail of nutritional supplementation under the ICDS scheme irrespective of whether or not they are registered in the area (see Box 3). As a result, all migrant children can benefit from anganwadi services in or near the nakas. Pregnant women will also be able to avail of antenatal and post-partum care through these anganwadis, which will be linked to government health services. Adolescent girls will be given treatment for anaemia at these anganwadis; in addition, they will be provided life skills and sex education through the ICDS programme. Disha has played a role in identifying sites for the establishment of anganwadis that are convenient for migrants as well as encouraging migrants to make use of the facilities.

\section{School enrolment}

Through discussions with the community, it became clear that schooling for the children was a key concern. Few children were enrolled in school although their parents valued education for their children. Underlying these low levels of school enrolment was the misperception that as temporary residents in the destination city, children of seasonal migrants were ineligible to avail of state-supported educational facilities. A similar misperception existed among school authorities and teachers who maintained that since migrant children could not be enrolled at the beginning of the school year, were likely not to remain in school until its end and rarely attended school regularly, they were ineligible for enrolment.

Initiatives to enable access to schooling focused on both opening up school slots for migrant children and on ensuring regular attendance among migrant children once admitted. Efforts at opening up school slots included mediation efforts with the school authorities in Nashik to allow children to join school temporarily while seasonal migrants were resident in the city. Several options for school enrolment ensued. Authorities agreed 


\title{
Extract from the ICDS Guidelines No. 620/2006/22.5.06
}

\author{
Office of the Commissioner \\ Integrated Child Development Services \\ Raigarh Bhawan, Rear Wing, First Floor \\ CBD, Belapur \\ 22 May 2006
}

\section{Sub: Central Government directive regarding nutritional supplementation}

Ref:

1. Central Government letter no. 1-5/92-Cd-2 dated 6.11 .1992

2. Central Government letter no. 19-5/2003-Cd (PT) dated 7.3.2006

3. Central Government letter no. 1-2/2006-CDI dated 8.3.2006

4. Department of Women and Child Development letter no. ABV 2006/No. 80/dated 15.4.2006

With reference to Central Government letter no. 1, all pregnant and lactating mothers and their children should be eligible under ICDS for nutritional supplementation and should be allowed to take advantage of all other services of ICDS. All pregnant and lactating mothers and their children (6 months to 6 years) who are not registered with ICDS anganwadis are also eligible to receive nutritional services under ICDS.

All beneficiaries who migrate should be provided a certificate from the anganwadi in their village of origin. When they migrate to other villages/towns, they should carry the original certificate with them and should submit it in the anganwadi at the destination so that they can avail of uninterrupted services. A copy of the certificate is annexed.

Central Government letter no. 19-5/2003-Cd (PT) dated 7.3.06 has the following clarifications on nutritional supplementation:

The Government has not fixed a precise number of beneficiaries for each anganwadi for the distribution of nutritional supplementation. There is no upper or lower limit for beneficiaries but the number of beneficiaries is expected to vary according to the population.

All anganwadis should register all children below the age of 6 years and all pregnant and lactating mothers for the purpose of nutritional supplementation. It is mandatory to provide nutritional supplementation to all children below 6 years. ICDS services are applicable not just to malnourished children but to all children in this age group as well 
as pregnant and lactating mothers. The ICDS scheme is open to all and not just to children and women below the poverty line. The scheme is in no way linked to income category or the nutritional status of the beneficiary.

The Commissioner

Integrated Child Development Services

State Government of Maharashtra

Copy:

1. Dy. Chief Executive Officer, Zilla Parishad

2. Child Development Project Officer, Urban (Nashik)

Copy submitted for information:

Secretary, Department of Women and Child Development, Mantralaya, Mumbai

\section{Copy of Certificate for Mothers and Children}

Copy of certificate for beneficiaries who migrate to other villages/towns to allow them to avail of ICDS services

\begin{tabular}{|c|c|c|c|c|c|}
\hline $\begin{array}{l}\text { Name of } \\
\text { beneficiary }\end{array}$ & $\begin{array}{l}\text { Name of ICDS } \\
\text { project in } \\
\text { village/town at } \\
\text { place of origin }\end{array}$ & $\begin{array}{l}\text { Beneficiary's } \\
\text { current } \\
\text { nutritional } \\
\text { status and } \\
\text { illnesses if any }\end{array}$ & $\begin{array}{l}\text { If beneficiary } \\
\text { is } \\
\text { malnourished, } \\
\text { degree of } \\
\text { malnutrition }\end{array}$ & $\begin{array}{l}\text { Name of } \\
\text { ICDS project } \\
\text { to which } \\
\text { beneficiary is } \\
\text { migrating }\end{array}$ & Remarks \\
\hline & & & & & \\
\hline
\end{tabular}

Signature of ICDS Project Officer in village/town/anganwadi at place of origin

Signature of ICDS teacher/worker in village/town/anganwadi at place of origin

(Translated from Marathi) 
that children would be allowed to enrol in municipal schools on the condition that they attended regularly (at least 45 days a term). Efforts also included discussions with the Nashik Municipal Corporation and the Education Department that led to the sanctioning of a school in the Civil naka for 20 migrant children under the Sarva Shiksha Ahbiyan with school hours to suit the convenience of migrant families. For those who preferred to find permanent schooling for their children, links were made with ashram (boarding) schools close to seasonal migrants' villages of origin to enrol migrant children. And finally, 3-4 private schools in the environs of the nakas have been motivated to accept migrant children and waive fees for them.

Efforts at ensuring regular attendance included awareness raising measures for seasonal migrants that highlighted the need to ensure regular attendance at schools and enable children to appear for their final examinations in each class. In addition, project representatives have facilitated the process of coordination between school authorities, migrant parents and children, arranged for free coaching of migrant children by local teachers and encouraged local residents to raise funds to meet the educational expenses of migrant children. The project organised six visits by Nashik Municipal Corporation and ICDS authorities to the four nakas concerning issues related to schooling, and the provision of balwadis for the children of seasonal migrants.

Despite these efforts, relatively few children are in school. As a result of the project's initiatives, nine migrant children have been admitted to regular municipal schools- two in ashram schools and seven in private schools. Twenty-five children were enrolled in the newly-established Civil naka school. School attendance and performance are reported to be good, with 25 children attending at least 45 days. As with other project activities, while only a few benefited, the intervention demonstrates it is possible for seasonal migrants to access existing services; however, these efforts have to be universalised if they are to be sustainable.

\section{Building livelihood skills}

In interactions, migrant communities identified the need to overcome lack of livelihood skills and economic opportunities; and expressed the need for training and skill building to strengthen their employment opportunities, and increase their daily wage earnings. As in the case of increasing access to schooling, the project acted to enhance livelihood skills by apprising seasonal migrants of available livelihood skill building programmes and working with training institutions to facilitate migrant attendance.

I get Rs. 60-80 a day for casual work and my wife gets Rs. 40-50 for the same work. A Bihari mason [skilled migrant from Bihar] gets Rs. 200-300 a day. (Male migrant, 29 years, Old Gangapur naka)

With regard to training programmes, few seasonal migrants were able to identify the kinds of training they desired. Most commonly expressed was the need for training in masonry and plumbing, explained by the fact that the majority of migrant workers tended to be 
engaged in construction activities. Given that seasonal migrants were by and large unaware of the array of training programmes available, eligibility criteria and admission procedures, the project undertook activities to raise awareness, inform seasonal migrants of different available programmes and their admission procedures, and facilitate access to these programmes. Authorities from vocational colleges also visited the nakas. Women were encouraged by the project to attend the training programmes in masonry and plumbing, which are regarded as traditional 'male' skills, which could enhance their earning capacity.

The project made special efforts to raise awareness of and facilitate livelihood skills training for young people, particularly young women. For example, training was organised for adolescent girls on managing balwadis, mehendi (hand-painting with henna), rangoli (floor decoration) and making leaf plates. In addition, market links were developed for the sale of leaf plates. Young women also identified the need to develop skills such as using the telephone, and such demonstrations were conducted by the project.

Efforts were also made at the institutional level. The project mediated with government and private institutes to provide training to seasonal migrants, and as a result two training sessions were organised on masonry and one session on plumbing. Seasonal migrants who indicated a willingness to join the course and forgo work for the period of training were selected.

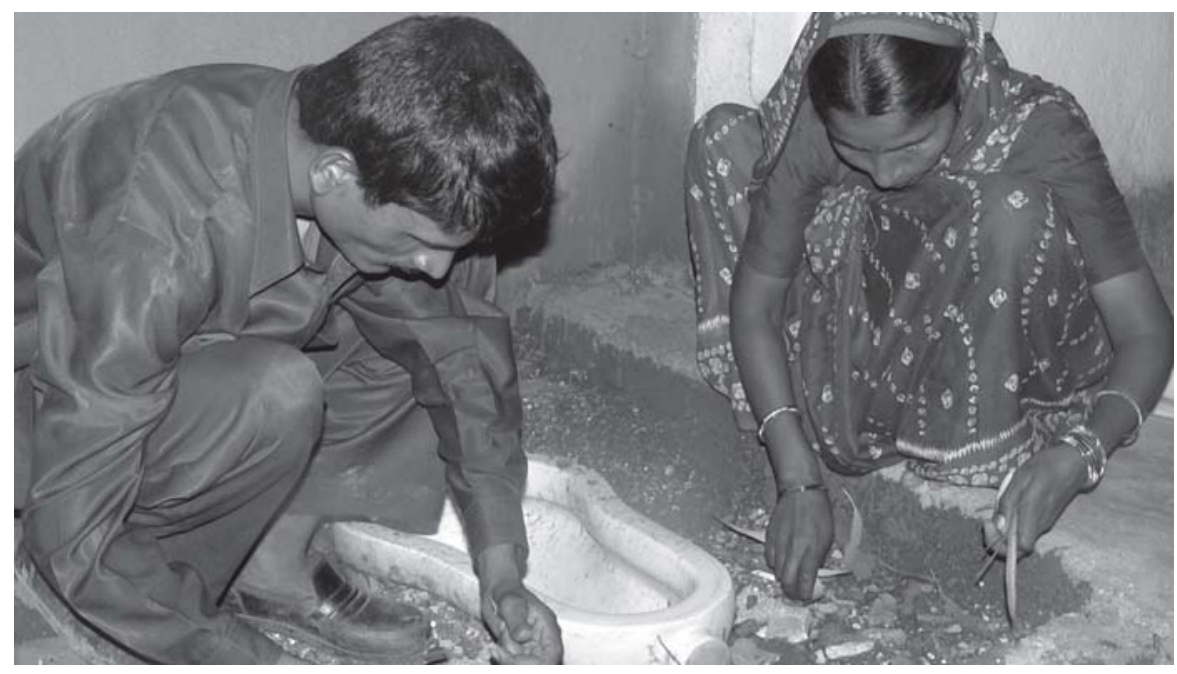

Building livelihood skills among migrant women and men

Arrangements for payment of fees varied from course to course; for some courses, training institutions agreed to reduce fees for participation for seasonal migrants who were unable to afford the fees. For the plumbing and masonry courses, the project met the entire cost of training and shared the costs of admission with participants, respectively. 
The project also made efforts to link trained seasonal migrants with institutes to provide them employment opportunities. For example, the project built linkages with the Plumbers' Association and the Nashik Municipal Corporation to employ trained naka workers to assist them in plumbing work. Similarly, the project has linked up with the Builders Association, Nashik to provide work opportunities to trained masons from the naka. As a result of their newly-acquired skills in plumbing and masonry, seasonal migrants have been able to negotiate higher wages.

I have started getting plumbing work. The certificate [for plumbing training] helps me a lot. When I show the certificate to the contractor, my wages are almost double. I earn Rs. 100-120 a day, when earlier I used to get Rs. 30-60 a day for rag picking or bigari [assistant to the mason]. (Female migrant, 26 years, Civil naka)

A total of 71 seasonal migrants men (47 women and 24 men) were trained through the project, of whom 41 were assisted in finding a temporary job (ranging from a week to 3 months). In all, 34 men and women were trained in masonry and plumbing, and 37 women were trained in leaf-plate making, mehendi and rangoli. Four seasonal migrants have been linked to permanent jobs.

\section{Access to financial security: Promoting savings and insurance}

Project implementers observed that seasonal migrants are sometimes forced to go for days without wages, and therefore needed a means of savings and insurance. Sessions were held on financial management to encourage savings formation. Because of their mobile lives and the temporary nature of their stays in Nashik, seasonal migrants were unwilling to save in a formal institution or scheme in the city. Some reported that they held bank accounts or were members of self-help groups in their home villages and hence did not wish to open accounts in Nashik. Despite these reservations, seven migrants did indeed use project assistance in opening savings accounts.

Project implementers also noted that seasonal migrants are entitled to take advantage of a life insurance scheme for workers in the unorganised sector (Janashri Vima Yojana) supported by the state and central government. Payments for disability, and accidental or natural death, and educational support for two children are provided under this scheme. The project has facilitated the formation of groups to invest in this scheme. So far, 25 seasonal migrants have joined the scheme and have voluntarily made an investment of Rs 100 each. Seasonal migrants have been given copies of the policy and made aware of the circumstances under which they are entitled to receive money.

The project has identified and trained key persons in each naka to be community leaders and to assist seasonal migrants in financial management efforts. In Civil naka, for example, local persons have been trained to fill up forms for seasonal migrants for insurance schemes and to collect payments for the premium. 
Table 3:

Addressing seasonal migrants' basic needs through project support

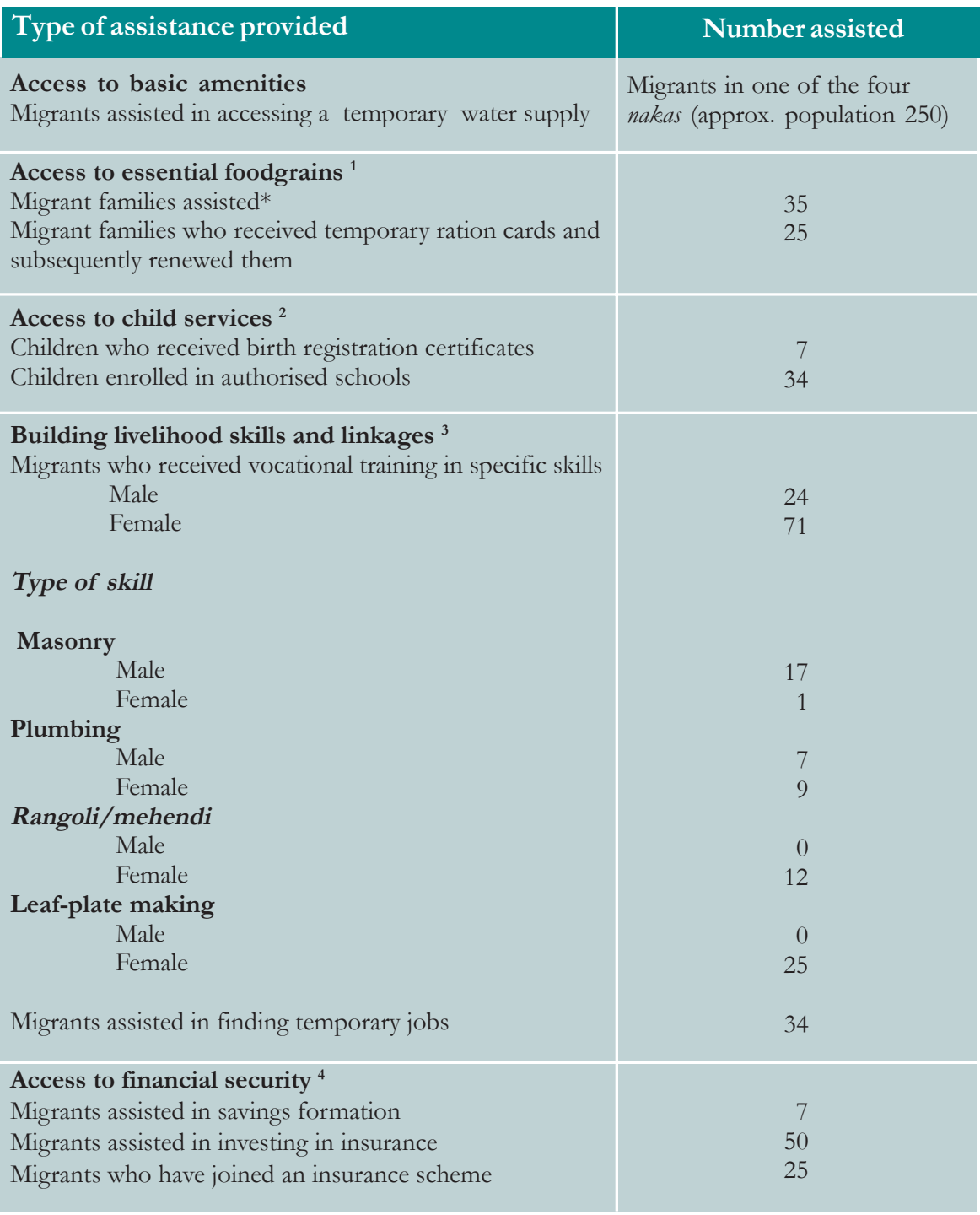

* Assisted in filling in form for temporary ration card. Ten migrants were unable to receive a ration card due to lack of documentary proof.

${ }^{1}$ Out of 351 households.

${ }^{2}$ Approximate number of children aged $0-15=265$.

${ }^{3}$ Approximate number of persons aged $15+=758$.

${ }^{4}$ Out of 351 bouseholds. 


\section{Conclusion and lessons learned}

This report describes a project to address the socio-economic needs of seasonal migrants in four nakas in Nashik, Maharashtra. The intervention spanned a relatively short period of 10 months - from October 2004 to June 2005 — covering the period of stay of seasonal migrants in Nashik. As noted earlier, seasonal migrants are a highly vulnerable population as a result of poor awareness of their rights and consequently their inability to demand their entitlements. Moreover, they are socially isolated in the destination city and their employment uncertain.

While the initial objective of the project was to address the health needs of the migrant population, in particular their sexual and reproductive health needs, the approach was expanded to improve the quality of their lives based on additional priorities identified by seasonal migrants. Recognising their vulnerability, the project sought to make seasonal migrants aware of their rights and entitlements to government services in the destination city, and to establish linkages between seasonal migrants and the authorities to facilitate seasonal migrants' access to these services.

As a result of the project's efforts, the short-term gains for seasonal migrants have been immense. Migrants gained access to basic amenities including water supply, and were enabled to access essential foodgrains through the issue of temporary ration cards. In addition, child-care services were introduced, children were enrolled in schools and birth registration certificates issued. The project also helped to build confidence in seasonal migrants to access health care services on their own, including those relating to sexual and reproductive health. The project responded to a key need articulated by seasonal migrants - to develop vocational skills — by organising training programmes and linking seasonal migrants with job opportunities; in addition, the project provided seasonal migrants access to financial security through insurance schemes.

Lessons drawn from the project show that while an administrative framework does exist to ensure that seasonal migrants are able to access services, it is necessary to both motivate the population and activate the authorities to ensure access to and delivery of these services. Enabling seasonal migrants to access services, building awareness and advocacy is however, a slow process.

At the same time, the sustainability of project interventions remains a question mark. In most cases the number of beneficiaries has been small, and services provided have not been sustainable as systems have not been set up that can support these efforts in the long run. And in the case of services, it is difficult to sustain the motivation of temporary migrants to adhere to the often time-consuming processes of obtaining services and accessing their rights. Consequently, while the project has been able to establish benefits for the population, these have generally been short-term gains, and often at a crisis management level, for example, authorities supplying water to naka residents for a short period only after the outbreak of an epidemic of scabies. In other cases, processes have 
been initiated and are on-going, with beneficiaries still requiring handholding assistance, e.g. the issue of temporary ration cards, identity cards and birth registration certificates. Some activities have been able to demonstrate success and sustainability, for example, the setting up of a day-care centre for children which was eventually taken over by the Nashik Municipal Corporation's balwadi.

In short, the project highlights that in order to address the needs of seasonal migrants one must work at both the level of the population of seasonal migrants and the administration. A variety of priorities and concerns need to be addressed that influence their lives. Moreover, one must work to enable seasonal migrants to gain access to services to which they are entitled, as well as to apprise them of their rights and support them to access their rights. This project has had limited success in making this population self-sufficient as a result of their mobility, the nature of their irregular migration to destination cities, and the difficulty in tracking seasonal migrants. The project has had some success in galvanising the administration but it is apparent that seasonal migrants will continue to need a mediator to help them address their multiple needs. The lessons learned from the implementation of this project are valuable, and should have wider application among similarly disadvantaged mobile populations across the country. 


\section{References}

Delor, F. and M. Hubert. 2000. "Revisiting the concept of vulnerability," Social Science and Medicine 50:1557-1570.

Guest, P. 2002. Migration and the spread of HIV/AIDS. Unpublished paper.

Registrar General, India (RGI). 2001. < http:/ /www.censusindia.net/results/dseries/ Tables_on_Migration_Census_of_India_2001.html > accessed on 6 June 2006.

Skeldon, R. 2000. Population mobility and HIV vulnerability in South East Asia: An assessment and analysis. Bangkok, United Nations Development Programme.

World Bank. 2002. South Asia Region (SAR) -India Regional Updates

< www.worldbank.int, India HIV/AIDS Update 2002> accessed on 6 June 2006. 


\section{Acknowledgements}

Several people provided invaluable assistance during the course of the project, and I would like to acknowledge their contribution: Mr Rameshchandra Sagar, Former Tribal Commissioner, Department of Tribal Development, Nashik; Mr Rajesh Kumar, Tribal Commissioner, Department of Tribal Development, Nashik; Mr V.S. Patil, Joint Tribal Commissioner, Nashik; Mr Mahesh Zagde, Collector, Nashik; Mr Rahne, Town Planner, Urban Land Ceiling, Nashik; Mr Shekhar Gaikwad, Addl. Collector, Nashik; the Resident Medical Officer and Civil Surgeon, Civil Hospital, Nashik; staff of the Health Department, Urban Health Centres, Water Supply Department and the Education Department of Nashik Municipal Corporation; Maharashtra State Electricity Board staff, Nashik; the Police Commissioner's Office, Nashik; Mr Dalvi, Principal, ITI College, Nashik; and Mr S.N. Batliwalla, Secretary, Sir Dorabji Tata Trust, Mumbai. Brig. N.L. Srivastava, Director, Leslie Sawhny Centre, Devlali, Nashik provided a training centre for migrant workers, for which we are grateful.

I would like to thank Shireen Jejeebhoy, K.G. Santhya, Shveta Kalyanwala and Komal Saxena at the Population Council for their guidance throughout the project and on previous versions of this report. I am grateful to Leela Visaria for reviewing the paper; Deepika Ganju for her editorial contribution; Vijaya Nidadavolu for overseeing production of the report; and Asha Matta for designing the report.

I am grateful to Adv. Milind Babar, Lokvikas Samajik Sanstha, Nashik; Dr. R.R. Goud, SOS Foundation, Nashik; and staff at the NGOs Lokvikas and Abhiyakti for their contribution to the project. And finally, I would like to thank all the migrants who participated in the project. 
